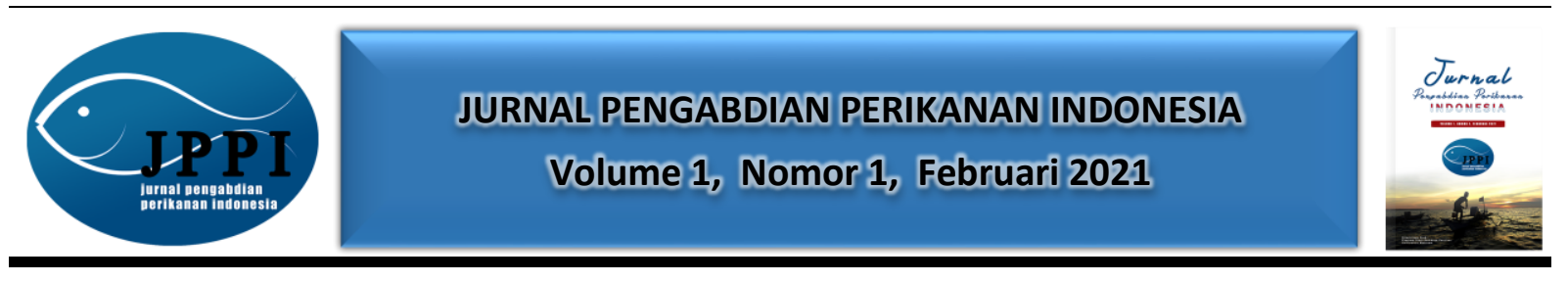

\title{
PENGEMBANGAN WIRAUSAHA KELOMPOK WANITA TANI DESA LOA KULU KOTA MELALUI PENGOLAHAN IKAN NILA
}

\author{
Masayu Widiastuti ${ }^{1}$, Robin Kurnia ${ }^{2}$, Rizal Ramadhan ${ }^{3}$ \\ Program Studi Teknik Sipil Universitas Mulawarman, Samarinda
}

Alamat korespondensi : masayuwidi@ft.unmul.ac.id

(Tanggal Submission: 3 Desember 2020, Tanggal Accepted : 2 Februari 2021)

\section{Keyword : \\ amplang, ikan nila, loa kulu kota}

\begin{abstract}
:
Loa Kulu Kota merupakan salah satu Desa Mandiri yang berada di Kabupaten Kutai Kartanegara Kalimantan Timur. Berdasarkan data yang diperoleh ternyata Desa Loa Kulu Kota merupakan lumbung penyedia ikan Nila terbesar di Kabupaten Kutai Kartanegara sehingga Desa ini memiliki potensi yang tinggi dalam bidang perikanan, namun belum dikembangkan secara maksimal sebagai sumber penghasilan masyarakat. Hal ini dikarenakan rendahnya ketrampilan dan pengetahuan masyarakat dalam pengelolaan potensi yang ada di Desa. Selama ini Kelompok Wanita Tani Desa Loa Kulu Kota telah melakukan usaha olahan ikan berupa kerupuk Amplang dari ikan Belida, namun ikan Belida sering mengalami kendala ketersediaannya, sehingga usaha ini menjadi tersendat. Dengan melihat potensi yang dimiliki Desa dan permasalahan tersebut, melalui kegiatan KKN 46 Kondisi Luar Biasa (KLB) Universitas Mulawarman berupaya membantu untuk meningkatan pemahaman dan pengetahuan masyarakat dalam inovasi produk olahan ikan dengan kegiatan penyuluhan, pelatihan dan pendampingan untuk mengembangkan wirausaha masyarakat khususnya kepada Kelompok Wanita Tani Desa Loa Kulu Kota, mengenai cara memproduksi pengolahan ikan Nila menjadi kerupuk mentah dan Abon ikan Nila. Metode dilakukan dengan memberikan pengetahuan (penyuluhan), demonstrasi serta peragaan melalui video dan pendampingan serta berdiskusi secara virtual dengan aparat Desa dan Kelompok Wanita Tani. Dari kegiatan pengabdian masyarakat ini Aparat Desa dan KWT merasa sangat terbantu karena sudah dapat pengetahuan untuk mengembangkan wirausaha melalui pengolahan ikan Nila. Dan saat ini Kelompok Wanita Tani sudah memproduksi kerupuk ikan Nila untuk penyediaan ke luar Desa dan ke luar Kalimantan Timur.
\end{abstract}

Panduan Sitasi (APPA $7^{\text {th }}$ edition) :

Widiastuti, M., Kurnia, R., \& Ramadhan, R. (2021). Pengembangan Wirausaha Kelompok Wanita Tani Desa Loa Kulu Kota Melalui Pengolahan Ikan Nila. Jurnal Pengabdian Perikanan Indonesia, 1 (1), 1-6. https://doi.org/10.29303/jppi.v1i1.36

\section{PENDAHULUAN}

Loa Kulu Kota merupakan salah satu Desa Mandiri yang berada di Kabupaten Kutai Kartanegara, Kalimantan Timur. Berdasarkan profil Desa diperoleh data bahwa luas Desa ini 2762,31 Ha dengan jumlah penduduk sebanyak 7.199 orang, dan umumnya masyarakat bekerja sebagai petani, peternak, wiraswasta dan pegawai negeri sipil. Potensi desa berada di sektor pertanian dan keramba/kolam ikan air tawar seperti ikan Nila, ikan Mas, dan ikan Lele. Hasil produksi keramba 1.328.296,8 ton/tahun dan hasil kolam adalah 3.750.600 ekor ikan. sehingga Desa ini memiliki potensi yang tinggi dalam bidang perikanan. Dari informasi kepala desa Bapak Mohamad Rizali. SP., 
desa ini menjadi lumbung penyedia ikan Nila di Kabupaten Kutai Kartanegara. Dengan predikat Desa Mandiri saat ini, aparat dan masyarakat berupaya menggiatkan kegiatan dari berbagai sektor untuk meningkatkan perekonomian dan kesejahteraan masyarakat, salah satu upaya yang cukup berhasil telah dilakukan adalah peran Kelompok Wanita Tani (KWT) melakukan wirausaha Amplang Ikan Belida yang menjadi ciri khas oleh-oleh Kalimantan Timur. Namun seringkali produksi Amplang menjadi tersendat, karena terbatasnya ketersediaan bahan baku ikan Belida yang didatangkan dari luar desa.

Sementara ikan Nila yang melimpah dari hasil desa hanya dimanfaatkan masyarakat sebagai lauk olahan rumah tangga, dan belum pernah dimanfaatkan menjadi produk olahan ikan yang bernilai ekonomis. Pengetahuan dan ketrampilan masyarakat khususnya anggota KWT dalam mengolah ikan air tawar (ikan Nila) menjadi suatu produk bernilai masih sangat kurang. Sebagai bahan pangan, kedudukan ikan menjadi sangat penting karena mengandung protein yang cukup tinggi sehingga digolongkan sebagai sumber protein (Tien Muchtadi, 2010). Ikan merupakan komoditi yang sangat potensial dalam masyarakat, tubuh ikan memiliki protein serta air yang cukup tinggi sehingga menjadi media yang baik bagi pertumbuhan mikro organisme pembusuk, oleh karenanya ikan menjadi komoditi yang mudah rusak. Salah satunya dengan penerapan teknologi pasca panen untuk mengolah ikan menjadi produk olahan yang bernilai ekonomi dan mempunyai umur simpan yang lebih lama (W. David Downey, 1992). Daging ikan merupakan bahan yang dapat diolah menjadi berbagai produk pangan seperti sosis, baso, nugget (Hadiwiyoto 1993),

Berdasarkan potensi dan permasalahan yang dimiliki Desa, maka kegiatan pengabdian masyarakat melalui kegiatan KKN 46 Kondisi Luar Biasa (KLB) Universitas Mulawarman, bertujuan membantu meningkatkan pengetahuan dan ketrampilan masyarakat dengan kegiatan penyuluhan, pelatihan dan pendampingan untuk memanfaatkan potensi ikan air tawar dan mengembangkan wirausaha masyarakat khususnya pada Kelompok Wanita Tani Desa Loa Kulu Kota mengenai inovasi produk olahan ikan Nila. Dan untuk mendukung peningkatan konsumsi ikan bagi masyarakat, agar produk olahan ikan dapat diterima masyarakat serta berpotensi besar untuk dipasarkan dan bernilai ekonomis, maka olahan ikan Nila dibuat berupa kerupuk dan abon. Mengolah daging ikan menjadi abon dan kerupuk merupakan alternative memperpanjang waktu simpan bahan sehingga tahan lama untuk tetap layak dikonsumsi karena Kerupuk dan Abon merupakan produk pangan yang bersifat kering dan ringan.

Sebagai komoditi dagangan kerupuk termasuk kedalam jenis produk industri yang mempunyai potensi cukup baik. Saat ini pemasarannya berkembang tidak hanya di dalam negeri, tetapi juga di luar negeri seperti Belanda, Singapura, Hongkong, Jepang, Suriname dan Amerikan Serikat (Sutrisno Koswara,2009).

\section{METODE KEGIATAN}

Metode pelaksanaan kegiatan pengabdian masyarakat melalui kegiatan KKN di masa Pandemi Covid 19 ini mengharuskan mahasiswa dan dosen untuk tidak langsung berinteraksi dengan masyarakat desa. Adapun metode kegiatan pada program yang dilaksanakan adalah :

1) Melakukan koordinasi awal antara Dosen dan Mahasiswa, selanjutnya dengan aparat Desa untuk mengenali kondisi desa dan mendapatkan data Profil Desa

2) Pengajuan program kegiatan yang disampaikan pada saat koordinasi dengan aparat Desa beserta masyarakat, dan pada tahap ini terdapat penyesuaian kegiatan terhadap kebutuhan dari kondisi 
permasalahan desa yang dikumpulkan dengan pendekatan partisipatif melalui hasil wawancara secara virtual (melalui Zoom dan Whatsapp), sehingga khalayak sasaran dapat berperan aktif dalam setiap kegiatan dan penyelesaian masalah.

3) Berdasarkana identifikasi permasalahan, disusun pengembangan ide dalam solusi permasalahan berupa pengetahuan (penyuluhan), pengarahan dan pendampingan, diantaranya untuk peningkatan keterampilan dalam pengembangan wirausaha masyarakat khususnya kepada Kelompok Wanita Tani Desa Loa Kulu Kota, mengenai cara memproduksi pengolahan ikan Nila menjadi kerupuk mentah ikan Nila dan Abon ikan Nila.

4) Pembuatan video tentang pengolahan kerupuk ikan Nila dan Abon Ikan Nila sebagai media penyuluhan.

5) Metode penyampaian penyuluhan secara virtual melalui Zoom dengan tayangan video kepada kelompok Wanita Tani dan juga penyebaran file video melalui Youtube

6) Melakukan koordinasi sebagai pemantauan / monitoring penerapan program yang dilakukan oleh Kelompok Wanita Tani melalui Videocall saat proses pembuatan kerupuk dan abon

7) Mendapatkan koordinasi bahwa Kelompok Wanita Tani Desa Loa Kulu Kota sudah bisa memproduksi olahan kerupuk ikan Nila untuk memenuhi pemesanan dari luar Desa dan luar Propinsi Kalimantan Timur.

8) Dilakukan evaluasi program dengan ketua Kelompok Wanita Tani dan Kepala desa, untuk melihat dampak yang timbul setelah kegiatan dilaksanakan, dan hal yang perlu dibenahi atau dikembangkan pada masa mendatang. Sehingga diharapkan kegiatan yang dilaksanakan dapat membantu meningkatkan perekonomian mitra pada khususnya dan masyarakat Desa Loa Kulu Kota pada umumnya.

\section{HASIL DAN PEMBAHASAN}

Pelaksanaan kegiatan Pengabdian kepada Masyarakat dengan judul Pengembangan Wirausaha Kelompok Wanita Tani Desa Loa Kulu Kota Melalui Pengolahan Ikan Nila telah dilaksanakan sejak 8 Juli sampai 18 Agustus 2020, berjalan dengan lancar.

Tahap koordinasi awal, dosen mahasiswa dan kepala Desa mendiskusikan rencana kegiatan serta mengidentifikasi potensi serta permasalahan yang ada di Desa, melalui virtual (Zoom) karena kegiatan pada KKN 46 Kondisi Luar Biasa (KLB) peraturan menetapkan pembatasan bagi kami untuk tidak berinteraksi langsung antara mahasiswa, dosen maupun dengan masyarakat Desa dimasa Pandemi Covid 19 ini.

Pengumpulan data/informasi desa dilakukan melalui wawancara dengan aparat desa, masyarakat dan telaah terhadap dokumen profil desa. Selanjutnya dosen beserta mahasiswa menyusun program kerja dan menyiapkan berbagai bahan untuk peragaan dalam pembuatan video yang akan disosialisasikan pada pertemuan dengan masyarakat khususnya pada Kelompok Wanita Tani.

Pelatihan diawali dengan mentransfer pengetahuan kepada peserta mengenai pengetahuan tentang memahami potensi yang ada di Desa, dan mengenalkan fungsi dan manfaat bahan dasar yang digunakan berupa ikan Nila dan bahan pendukung lainnya, serta prosedur pengolahan ikan Nila menjadi kerupuk dan abon, serta peralatan yang digunakan, pengemasan produk dan faktor yang berpengaruh terhadap pengolahan hasil perikanan. Dan disampaikan juga pentingnya sanitasi dan higienis untuk diterapkan dalam proses produksi. Dalam pertemuan dilakukan diskusi dua arah 
sehingga peserta dapat lebih faham mengenai materi yang disampaikan., saat itu terlihat antusias peserta yang sangat baik karena banyak pertanyaan dan diskusi yang terjalin saat virtual (Zoom). Demonstrasi pembuatan produk olahan ikan dilakukan melalui tayangan video yang disampaikan dalam pertemuan online, koordinasi dan monitoring saat proses implementasi kegiatan oleh Kelompok Wanita Tani dilakukan melalui Videocall (whatsapp). Bahan baku utama yang digunakan untuk pembuatan kerupuk dan abon merupakan ikan Nila hasil panen di desa Loa Kulu Kota, sehingga kualitasnya masih baik dan segar. Peralatan yang digunakan dalam pengolahan produk juga peralatan yang terjangkau ketersediaannya di desa, dan sangat dimungkinkan Kelompok Wanita Tani dapat mengembangkan variasi olahan produk ikan lainnya karena memilik waktu kerja yang cukup. Pada tahap koordinasi akhir sebagai bentuk evaluasi kegiatan ini, diperoleh informasi bahwa Kelompok Wanita Tani desa Loa Kulu Kota sudah mampu memproduksi kerupuk ikan Nila dan abon ikan Nila yang sudah dikemas dan siap jual, bahkan produk kerupuk ikan Nila sudah diproduksi untuk memenuhi permintaan dari luar daerah. Selanjutnya aparat Desa dan Kelompok Wanita Tani mengharapkan adanya pembekalan melalui program PKM terkait proses perizinan produk, pelebelan, dan pengolahan ketahanan produk olahan makanan lainnya. Pengetahuan mengenai bahan baku dan diversifikasi produk perikanan pada saat sebelum dilakukan kegiatan pengabdian pada masyarakat belum diketahui dengan baik oleh masyarakat di desa Loa Kulu Kota.

Dengan adanya kegiatan PKM yang terintegrasi dengan kegiatan KKN Universitas Mulawarman di desa Loa Kulu Kota, masyarakat merasa terbantu dan menerima dengan baik adanya kegiatan ini, khususnya Kelompok Wanita Tani dalam mengembangkan wirausahanya melalui produk olahan ikan Nila, Pengetahuan mengenai keterampilan dalam mengolah berbagai produk hasil perikanan sangat diperlukan oleh masyarakat di wilayah Desa Loa Kulu Kota.Diharapkan dengan adanya kegiatan ini masyarakat dapat termotivasi untuk menciptakan produk olahan hasil perikanan lainnya dengan variasi rasa yang enak dan bergizi, sehingga produk olahan tersebut dapat dijadikan sebagai produk unggulan desa Loa Kulu Kota dan melalui produk olahan hasil perikanan, dapat meningkatkan perekonomian masyarakat.

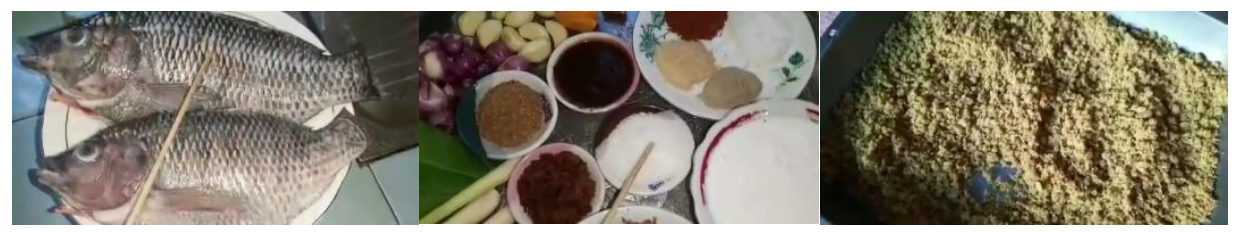

Gambar 1 Proses untuk pembuatan Abon ikan Nila

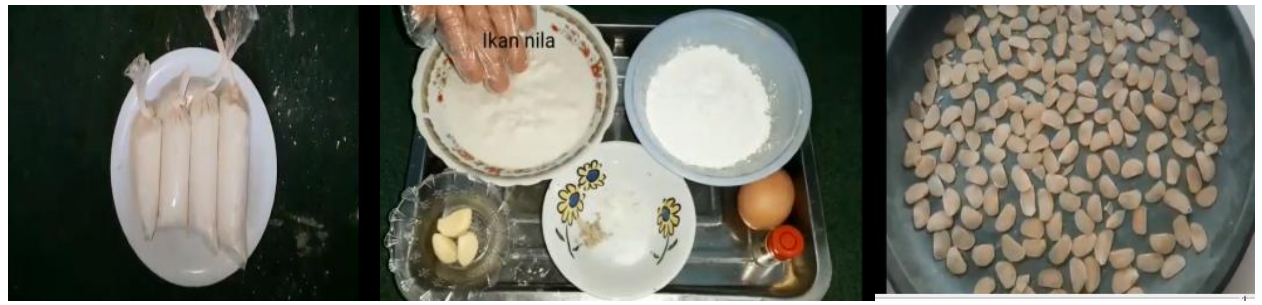

Gambar 2 Proses untuk pembuatan Kerupuk ikan Nila 


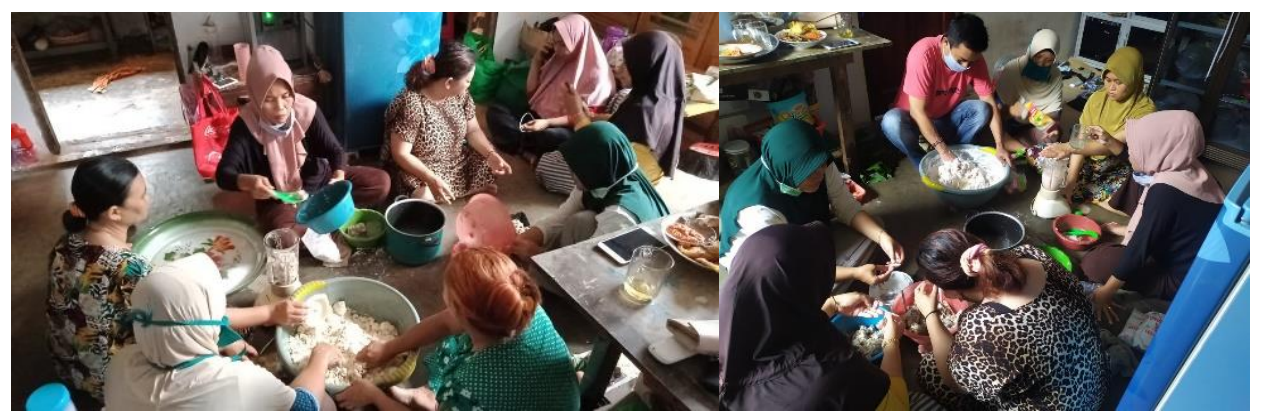

Gambar 3 Proses Pembuatan Olahan ikan Nila, oleh KWT Desa Loa Kulu Kota

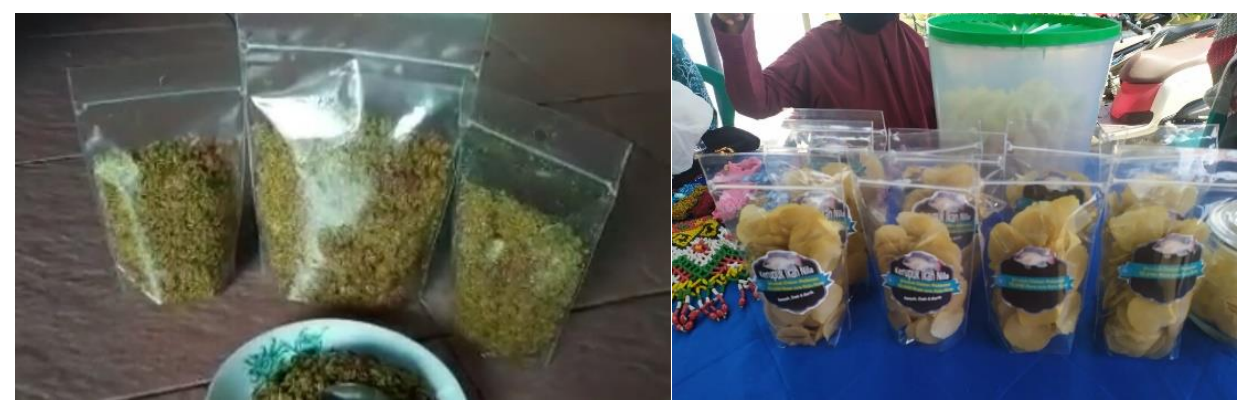

Gambar 4 Produk Olahan Abon ikan Nila dan Kerupuk ikan Nila

\section{KESIMPULAN DAN SARAN}

Dari program Pengabdian Kepada Masyarakat di Loa Kulu Kota Kabupaten Kutai Kartanegara melalui kegiatan KKN Kondisi Luar Biasa (KLB) tahun 2020 Universitas Mulawarman diperoleh hasil sebagai berikut :

1. Masyarakat merasa terbantu mendapatkan pengetahuan dalam memanfaatkan potensi yang ada di Desa dan Masyarakat bertekad meningkatkan produksi ikan Nila untuk menjadikan produk olahan yang memiliki nilai tambah.

2. Meningkatnya pengetahuan dan ketrampilan masyarakat utamanya pada Kelompok Wanita Tani dalam pengolahan ikan Nila menjadi Kerupuk dan Abon.

3. Kelompok Wanita Tani sudah bisa memproduksi kerupuk ikan Nila dan Abon, bahkan sudah memproduksi kerupuk ikan Nila untuk penyediaan keluar daerah

4. Terbukanya prospek pengembangan Wirausaha Kelompok Wanita Tani dari produk Kerupuk dan Abon ikan Nila, untuk meningkatkan perekonomian masyarakat Desa Loa Kulu Kota.

Dalam pengembangan kewirausahaan Kelompok Wanita Tani dari kegiatan pengolahan ikan Nila, disarankan :

1. Mengutamakan kualitas produk, meliputi bahan dasar yang digunakan, proses pengolahan dan pengemasan yang baik dan menarik.

2. Meningkatkan pengetahuan tentang pelebelan dan perizinan produk olahan makanan.

3. Meningkatkan penataan manajemen usaha Kelompok Wanita Tani sehingga menjadi lembaga yang maju untuk mendukung perekonomian Desa.

\section{UCAPAN TERIMA KASIH}

Penulis mengucapkan terima kasih kepada Lembaga Penelitian dan Pengabdian Masyarakat (LP2M) Universitas Mulawarman (SK Rektor No. 994/SK/2020 Tentang Dosen Pembimbing Lapangan 
Kuliah Kerja Nyata Kondisi Luar Biasa Tahun 2020) yang telah memberi dukungan financial terhadap pengabdian ini.

\section{DAFTAR PUSTAKA}

Downey, W.D., (1992). Manajemen Agribisnis, Ed.2. Erlangga: Jakarta.

Hadiwiyoto, S. (1993). Teknologi Pengolahan Hasil Perikanan. Liberty: Yogyakarta.

Sutrisno K. (2020). Pengolahan Aneka Kerupuk, http://tekpan.unimus.ac.id/wpcontent/uploads/2013/07/PENGOLAHAN-ANEKA-K-E-R-U-P-U-K.pdf, diakses tgl 2 Desember 2020.

Tie, M., Sugiyono., Fitriyono , A. (2010). Ilmu Pengetahuan Bahan Pangan. Alfabeta: Bandung. 